\title{
Lexical borrowing in Slovene green energy terminology
}

\author{
Laura Mrhar*
}

\begin{abstract}
The paper presents the most common types of lexical borrowing in Slovene green energy terminology and the languages this particular field generally borrows from, with a special emphasis on calques and doublets, which often occur as a result of borrowing from these languages, e.g., odlagališce (also: deponija) 'landfill', odlagališcni plin (also: deponijski plin) 'landfill gas', biotska raznovrstnost (also: biodiverziteta, biotska pestrost, biološka raznovrstnost) 'biodiversity', and albedo (also: odbojnost) 'albedo'.

The examples of lexical borrowing are taken from the English-Slovene Dictionary of Green Energy Terms (Mrhar 2015) and analyzed with the help of a small corpus compiled for the purposes of this study, containing a limited number of Slovene articles on green energy and their English translations. The paper furthermore concentrates on the variety of vocabulary deployed in texts pertaining to the field and assesses both unproblematic and problematic cases of lexical borrowing.
\end{abstract}

Key words: green energy terminology, lexical borrowing, calques, doublets, terminological dictionary

* University of Ljubljana; lauramrhar@gmail.com 


\section{The Issue of Loanwords in Slovene Green Energy Terminology}

The field of green energy is characterized by rapid development, which requires an exceptionally dynamic terminology, both in English and Slovene. Slovene green energy terminology is currently a rather sensitive linguistic area, mainly because of a vast influx of loanwords (especially different types of compounds), primarily borrowed from English, which can be attributed mostly to the impact of globalization and massive exposure to English in all areas of life (Šabec 2009, 20). The field of green energy is particularly susceptible to borrowing from other languages, either to find words for concepts formerly unknown and unexpressed by the Slovene language or to borrow words for concepts which already have native expressions. The term loanword (or lexical borrowing) is hereinafter used to describe all kinds of transfer of lexical material from one language (the donor language, e.g., English, Greek or Latin) to another language (the recipient language, i.e., Slovene) (Zenner and Kristiansen 2014, 1).

A large part of older green energy terminology that has been completely integrated into Slovene and no longer sounds foreign comes from classical languages, i.e., Greek and Latin, whereas newer terminology mainly comes from English or, rather, is first formed in English. Such terms can, however, have Greek or Latin components, e.g., the English term eco-anditor was formed in English, but the first part of the compound, eco-, comes from Greek, and the second part of the compound, auditor, comes from Latin $^{1}$. Both components of the Slovene translation ekorevizor originate in Latin as well ${ }^{2}$. When such words are borrowed from English to Slovene, a loan translation or calque is typically first established, and can be substituted by a native equivalent, in case the usage of the term is frequent enough (Erjavec 2010, 110) ${ }^{3}$.

A more in-depth research will show whether the majority of loanwords in Slovene green energy terminology originates in Greek and Latin or comes from other languages. It will also be shown if native expressions exist alongside borrowed expressions and which are used more often. The sample in this study consists of 300 terms taken from the revised English-Slovene Dictionary of Green Energy Terms (Mrhar 2015) ${ }^{4}$. The selection of words taken from GREET was first divided up into two groups, i.e., native Slovene expressions that were, according to their etymology, not borrowed from another language and words of foreign origin. The latter were then divided into two subsequent subgroups, i.e., the (mostly) multi-word calques and the single-word loanwords.

\footnotetext{
1 The etymology of the terms is taken from Duden: Das Große Fremdwörterbuch. Herkunft und Bedentung der Fremdwörter (1994).

2 The etymology for lexical items in Slovene comes from Veliki slovar tujk (2002).

3 All translations into English: Laura Mrhar.

4 Hereafter: GREET
} 


\section{Common Types of Lexical Borrowing in Slovene Green Energy Terminology}

There is a large amount of borrowed lexical material in Slovene green energy terminology, ranging from older loanwords, which have by now been completely integrated into the language and conform to the rules of Slovene grammar, to more contemporary borrowed expressions, which are borrowed directly from English and are much more vulnerable to variation (cf. Šabec 2009, 20-22). One of the most comprehensive taxonomies of borrowing, the most common type of transference between languages, was developed by Haugen $(1950,1956)$, who states that importation and substitution combine in the borrowing process, meaning that there are multiple outcomes of lexical borrowing, i.e., foreign words can be borrowed together with their meanings, or meanings can enter a language on their own. Haugen's taxonomy includes two main categories - loanwords and loanshifts (Greavu 2013, 96). Loanwords can be further categorized into pure loanwords and loanblends or, rather, hybrids, whereas loanshifts or, rather, calques, can be categorized into semantic loans and creations. In the following section of this paper we are going to illustrate these separate classes of borrowing with examples from GREET.

\subsection{Loanwords}

The first category in Haugen's classification of borrowing is that of loanwords. In the case of loanwords, the form and meaning of English and Slovene words are either identical or highly similar to each other. The borrowed word "may undergo a process of phonetic integration into the structures of the recipient language" (Greavu 2013, 97), and can be moderately to highly successful. To characterize a loanword as highly successful, it has to become the only occurring lexicalization for a given concept. The majority of loanwords extracted from GREET are nouns (1), which is not surprising, as nouns form by far the largest word class in all languages, and are borrowed the most.

(1)

- biodizel 'biodiesel'

- emisija 'emission'

- reciklaža 'recycling'

- toksin 'toxin'

- vegetacija 'vegetation', etc.

The considerable quantity of noun loanwords most likely has to do with grammatical factors; verbs are normally more difficult to borrow than nouns because they need more grammatical adaptation (Haspelmath 2009, 35). There is, however, a small number of loan adjectives (2), and an even smaller number of loan verbs (3). 
(2)

- alternationi 'alternative'

- ekološki 'ecological'

- radioaktioni 'radioactive'

- toksični 'toxic', etc.

(3)

- destilirati 'distil'

- izolirati 'insulate'

- reciklirati 'recycle', etc.

\subsection{Hybrids}

The second category in Haugen's classification of borrowing is that of loanblends or hybrids. For the purposes of this article, hybrids are not treated as a separate category in the classification of borrowing but rather as a subcategory of loanwords, as hybrids are in fact loanwords, in which "a part of the phonemic shape of the word has been imported, while a native portion has been substituted for the rest" (Haugen 1950, 214). In green energy terminology, the terms biogorivo 'biofuel', biohrana 'bio food', biokmetovanje 'organic farming', biovrtnarjenje 'biogardening' and ekokmetija 'eco farm', represent this type of borrowing. It is usually the second part that is not borrowed, since preserving the native part as the second (inflected) part of the word makes morphological adaptation easier ${ }^{5}$. Considering the structural patterns of hybrids, the most common are noun + noun combinations, proving that "among hybrids, compound nouns are by far the largest group. [...] This is indicative of the general dominance of nominal borrowings over verbal and adjectival loans" (Onysko 2007, 56).

\subsection{Calques}

The third category in Haugen's classification of borrowing is that of loanshifts or calques. Calques or word-for-word translations taken from GREET can include one or more words of foreign origin and one or more words of native origin (4), two or more words of native origin (5), or two or more words of foreign origin (6).

(4)

- alternativna energija 'alternative energy'

- biotsko ravnovesje 'biotic equilibrium'

- zelena energija 'green energy'

\footnotetext{
5 Slovene linguists describe these as "compounds with replacement (borrowed) elements in the syntactic base" (Vidovič Muha 2011, 296).
} 
(5)

- podnebna sprememba 'climate change'

- wcinek tople grede 'the greenhouse effect'

- varstvo okolja 'environmental protection'

(6)

- aktioni biomonitoring 'active biomonitoring'

- ekoloska toleranca 'ecological tolerance'

- sekundarna energija 'secondary energy'

Foreign lexemes are present in nearly all Slovene reproductions, with the possible combinations: 1.) native adjective + foreign noun: zelena revolucija 'the green revolution', 2.) foreign adjective + native noun: agresivna voda 'aggressive water', or 3.) foreign adjective + foreign noun: antropogeni stres 'anthropogenic stress'. Anglo-Slovene combinations are much more frequent than reproductions consisting exclusively of native elements: podnebna sprememba 'climate change'.

\section{Donor Languages}

For the purposes of this analysis, all 300 terms extracted from GREET were categorized according to their etymological origin ${ }^{6}$ and divided amongst native expressions, calques and loanwords, with merely a small section of the division presented in Table 1. Out of 300 analyzed expressions, 70 were categorized as native (unborrowed) Slovene, 81 as calques and 149 as loanwords. The majority of analyzed (primarily single-word) loanwords in Slovene green energy terminology is borrowed in a straightforward way from Greek and Latin, e.g., anabioza 'anabiosis', anoksija 'anoxia', biom 'biome', favna 'fauna', flora 'flora'. The two languages represent the common heritage of European languages, and can thus be characterized as internationalisms, most commonly found in the fields of medicine, natural sciences, social sciences and the humanities (Vidovic Muha 2004, 74-78). Such loanwords are unproblematic for green energy terminology. English is perhaps even more important as a donor language than Greek or Latin, as the better part of newer expressions, not only single-word loanwords (e.g., biodiverziteta 'biodiversity' or biomonitor 'biomonitor') but also multi-word loanwords (e.g., ekološko pomembno območje 'ecologically important area' or bibridno vozilo 'hybrid vehicle'), comes from the English language and enriches the terminological system of Slovene.

In the case of multi-word loanwords, individual elements often do not originate in English, but come from the classical languages. For example, in the multi-word term abiotski stress 'abiotic stress', the adjective abiotski 'abiotic' originates in Greek, whereas

6 The etymology for lexical items in Slovene comes from Veliki slovar tujk (2002). 


\begin{tabular}{|c|c|c|}
\hline Native & Calque & Loanword \\
\hline apnenec 'limestone' & $\begin{array}{l}\text { aktivni monitoring 'active } \\
\text { monitoring' }\end{array}$ & aeracija 'aeration' \\
\hline blato 'sludge' & $\begin{array}{l}\text { biotski okoljski dejavnik } \\
\text { 'biotic environmental } \\
\text { factor' }\end{array}$ & biocenoza 'biocenosis' \\
\hline drevesnica 'tree nursery' & $\begin{array}{l}\text { ekološka toleranca } \\
\text { 'ecological tolerance' }\end{array}$ & biodizel 'biodiesel' \\
\hline $\begin{array}{l}\text { elektrarna 'power plant' } \\
\text { gozdarstvo 'forestry' }\end{array}$ & $\begin{array}{l}\text { fosilno gorivo 'fossil fuel' } \\
\text { kisli dež 'acid rain' }\end{array}$ & $\begin{array}{l}\text { ekoturizem 'ecotourism' } \\
\text { fltracija 'filtration' }\end{array}$ \\
\hline blapnost 'volatility' & $\begin{array}{l}\text { trajnostni razvoj } \\
\text { 'sustainable development' }\end{array}$ & herbicid 'herbicide' \\
\hline izsekavanje 'deforestation' & $\begin{array}{l}\text { zelena revolucija 'green } \\
\text { revolution' }\end{array}$ & $\begin{array}{l}\text { klimatologija } \\
\text { 'climatology' }\end{array}$ \\
\hline
\end{tabular}

Table 1: Native expressions, calques and loanwords from GREET

the noun stres 'stress' originates in Latin. Similarly, in the multi-word term energijska bilanca 'energy balance', the adjective energijski 'energy' originates in Greek, and the noun bilanca 'balance' comes from Latin. In such cases, it can often prove problematic to determine the language from which the given term is borrowed into Slovene. In general, such terms are rather new, and have first been used or formed in English, from which they pass into other languages. We therefore normally say that these terms are borrowed from English, even though their constituent parts originate in the classical languages. The same holds true for a number of multi-word terms translated word-forword from English, in which the constituent parts are native, for example varstvo okolja 'environmental protection' or okljsko računovodstvo 'environmental accounting'.

The growing dominance of English can be attributed to its use as a lingua franca for international communication in various specialized fields (cf. Seidlhofer 2011), which is not to say other languages are not important in the borrowing process. On a much smaller scale, Slovene green energy terminology also borrows from Italian (e.g., izolacija 'insulation'), German (e.g., deponija 'landfill'), Arabic (e.g., katran 'tar'), and Persian (e.g., nafta 'oil'). These are the donor languages of the terms taken only from GREET; there are other donor languages in the case of Slovene green energy terminology, but they have not been mentioned here, as they do not occur in the analysis. 


\section{Doublets and Calques in Slovene Green Energy Terminology}

A special feature of green energy terminology is an extensive use of terminological doublets and triplets or, rather, lexemes sharing the same meaning, e.g., acidnost and kislost 'acidity', aeracija and prezračevanje 'aeration', aklimatizacija and prilagoditev 'acclimatization', albedo and odbojnost 'albedo', atmosfera and ozračje 'atmosphere', karbonizacija and oglenitev 'carbonization', which often prove to be problematic for the user of the specialized language and therefore attract much criticism, not entirely because of the fear that the loanword will replace the native word (cf. Crystal 2011, 69), but because of the non-uniform use of the given variants.

In the case of single-word terms, doublets most often consist of a loanword of Greek or Latin origin (e.g., aeracija 'aeration' or karbonizacija 'carbonization') and a native expression (e.g., prezračevanje 'aeration' or oglenitev 'carbonization'), whereas in the case of multi-word terms, doublets normally consist of a calque (e.g., klimatska sprememba 'climate change') originating in English, and a term in which native words substitute foreign components (e.g., podnebna sprememba 'climate change').

The main goal of GREET is to present standard or, rather, preferential terms in those cases in which one or more Slovene translation equivalents can be used for a single word or unit in English. Usually, native expressions are considered preferential, e.g., podnebje and not klima 'climate', oglenitev and not karbonizacija 'carbonization', sušnost and not aridnost 'aridity', but before any given expression can be included in a terminological dictionary, a more thorough analysis needs to be carried out to determine whether the terms that form a doublet are entirely co-extensive, and established within a particular field. The need for stability and predictability is especially strong in the case of academic texts which must have a predictable lexis and in which neologisms must remain within previously determined patterns (Kranjc and Žele 2014, 126).

\subsection{Corpus Analysis and Problematic Cases of Lexical Borrowing}

Within the framework of the translation process, one of the most effective methods of collecting evidence concerning various linguistic phenomena (e.g., borrowings) is the compilation of mono-, bi-, or multilingual corpora. As of yet, the Slovene area does not have a specialized corpus of scientific language that would enable quantitative or qualitative research of translation strategies and relationships between the original-language terms (e.g., English) and the foreign-language translation equivalents (e.g., Slovene). Slovene translation-related linguistic analyses would substantially benefit from a bilingual English-Slovene corpus of scientific or technical texts and their translations, which is why a small corpus was compiled for the purposes of the given analysis.

It contains 25 specialized texts or, rather, abstracts in either Slovene or English with their translations and key words. As the quantity of Slovene articles on green energy is highly limited, various other subject fields had to be consulted in the selection of articles 
to be included in the corpus, e.g., environmental protection, forestry, geology, geography, etc. Due to the shortage of Slovene articles in all fields, not just those pertaining to green energy, the analysis was highly limited in its scope and shows the current state of a small number of borrowed expressions.

Only 13 terms and their doublets taken from GREET were included in the analysis, as the number of their appearances in the articles was high enough to provide reliable data for further interpretation. Other green energy terms appear in the corpus, but not much data on actual use can be obtained from merely one or two appearances. To analyze a larger number of terms and their doublets from GREET, the corpus would have to include at least 100 articles or abstracts, which is currently impossible, as there is an acute shortage of representative specialized texts in Slovene (or English, with Slovene translations).

Besides showing the number of appearances of Slovene terms in the 25 specialized texts, the corpus also shows the number of appearances in the general corpus Gigafida ${ }^{7}$, thus providing data not only on specialized but also on general language. A word frequency analysis was carried out do determine whether native expressions are used more often than borrowed expressions or vice versa. The following table (Table 2) shows the list of analyzed terms and their concordances in the general corpus Gigafida and the small corpus of specialized texts, including the possible doublet(s) (e.g., the synonyms of biotska raznovrstnost 'biodiversity': 1.) biološka raznovrstnost, 2.) biotska pestrost, 3.) biodiverziteta).

The quantitative data presents the actual use of a number of green energy terms and their doublets in Slovene. The corpus analysis of native terms and their doublets, words borrowed from foreign languages, shows with some degree of certainty that in green energy terminology, native expressions are used as frequently as borrowed expressions. Some Slovene terms included in the table do not have any borrowed doublets (i.e. onesnaževanje / onesnaženje 'pollution' and podzemna voda / podtalnica 'groundwater'), but are included in the analysis to show which native expression is more frequent. Similarly, the borrowed expression biotska raznovrstnost 'biodiversity' is included in the analysis to show which of its borrowed doublets (i.e., biodiverziteta / biotska pestrost / bioloska raznovrstnost) is the most frequent.

The quantitative data presents the actual use of a number of green energy terms and their doublets in Slovene. The corpus analysis of native terms and their doublets, words borrowed from foreign languages, shows with some degree of certainty that in green energy terminology, native expressions are used as frequently as borrowed expressions. Some Slovene terms included in the table do not have any borrowed doublets (i.e. onesnaževanje / onesnaženje 'pollution' and podzemna voda / podtalnica 'groundwater'), but

\footnotetext{
7 An extensive Slovene corpus of authentic texts of various genres, built to serve as a research module for the modern Slovene language. It includes both texts from printed sources and the Internet, and can be used by language specialists, linguists, teachers, students, and pupils.
} 


\begin{tabular}{|c|c|c|c|c|c|}
\hline Preferential term & $\begin{array}{l}\text { Concordance } \\
\text { in Gigafida }\end{array}$ & $\begin{array}{r}\text { Concordance } \\
\text { in the corpus } \\
\text { of specialized } \\
\text { texts }\end{array}$ & $\begin{array}{r}\text { Non- } \\
\text { preferential } \\
\text { term }\end{array}$ & $\begin{array}{l}\text { Concordance } \\
\text { in Gigafida }\end{array}$ & $\begin{array}{r}\text { Concordance } \\
\text { in the corpus } \\
\text { of specialized } \\
\text { texts }\end{array}$ \\
\hline \multirow[t]{3}{*}{ biotska raznovrstnost } & 2.178 & 6 & $\begin{array}{l}\text { 1.) biološka } \\
\text { raznovrstnost }\end{array}$ & 1.) 440 & 1.) 0 \\
\hline & & & $\begin{array}{l}\text { 2.) biotska } \\
\text { pestrost }\end{array}$ & 2.) 492 & 2.) 1 \\
\hline & & & $\begin{array}{r}3 .) \\
\text { biodiverziteta }\end{array}$ & 3.) 832 & 3.) 5 \\
\hline vegetacija & 3.308 & 11 & rastlinstvo & 2.509 & 0 \\
\hline podnebna sprememba & 12.024 & 6 & $\begin{array}{r}\text { klimatska } \\
\text { sprememba }\end{array}$ & 3.076 & 5 \\
\hline emisija & 17.783 & 9 & izpust & 14.499 & 3 \\
\hline transport & 19.854 & 6 & prevoz & 84.933 & 2 \\
\hline odlagališče & 24.449 & 13 & deponija & 13.433 & 0 \\
\hline \multirow[t]{2}{*}{ onesnaževalo } & 5.332 & 7 & $\begin{array}{r}1 .) \\
\text { onesnaževalec }\end{array}$ & 4.227 & 3 \\
\hline & & & 2.) polutant & 233 & 1 \\
\hline urbani & 37.803 & 7 & mestni & 294.278 & 0 \\
\hline podzemna voda & 1.598 & 12 & podtalnica & 6.202 & 6 \\
\hline onesnaževanje & 12.107 & 7 & onesnaženje & 8.228 & 5 \\
\hline toksični & 2.002 & 4 & strupeni & 19.313 & 1 \\
\hline rastlinski & 25.203 & 3 & vegetativni & 1.307 & 1 \\
\hline podnebje & 12.057 & 10 & klima & 21.146 & 3 \\
\hline Monolinguals & 15 & 25 & 8 & 13 & 61 \\
\hline Bilinguals & 16 & 26 & 10 & 15 & 67 \\
\hline In total & 31 & 51 & 18 & 28 & 128 \\
\hline
\end{tabular}

Table 2: 13 terms and their doublets from GREET

are included in the analysis to show which native expression is more frequent. Similarly, the borrowed expression biotska raznovrstnost 'biodiversity' is included in the analysis to show which of its borrowed doublets (i.e., biodiverziteta / biotska pestrost / bioloska raznovrstnost) is the most frequent.

Out of 13 terms, 5 native and 5 borrowed expressions are classified as preferential (to be included in GREET as headwords, with other expressions listed as possible (nonpreferential) translation equivalents) due to the number of their appearances in the corpus. The 5 native expressions are odlagališce (and not deponija) 'landfill', onesnaževalo (and not polutant) 'pollutant', rastlinski (and not vegetacijski) 'vegetative', podnebje (and not klima) 'climate', podnebna sprememba (and not klimatska sprememba) 'climate change'. The 5 borrowed expressions are vegetacija (and not rastlinstvo) 'vegetation', 
emisija (and not izpust) 'emission', transport (and not prevoz) 'transport', urbani (and not mestni) 'urban', toksični (and not strupeni) 'toxic'.

Interestingly, the number of preferential borrowed expressions is relatively low, as it was first expected that borrowed expressions would be used more often than native expressions in Slovene green energy terminology. Perhaps the sample of articles included in the corpus was not representative enough to show the true state of borrowed expressions on the one hand and native on the other, or the considerable use of Slovene terms as opposed to borrowed ones shows that field specialists are in fact inclined towards using native Slovene terms and only use borrowed ones when there are no Slovene variants or when the borrowed expression is common to the extent that everybody uses it.

According to data obtained from the corpus, there are some cases that show inconsistent or, rather, problematic use of borrowed and native expressions, which suggests that some areas of Slovene green energy might not have been unified. In the case of vegetacija / vegetacijski 'vegetation / vegetative' and rastlinstvo / rastlinski 'vegetation / vegetative', the borrowed expression is used more often than the native expression in the case of the noun vegetacija (and not rastlinstvo) 'vegetation', whereas in the case of the adjective vegetacijski / rastlinski 'vegetative', the native Slovene expression rastlinski is used more often than the borrowed expression. The borrowed term vegetacija 'vegetation' has 3.308 occurrences in the general corpus Gigafida and 11 occurrences in the specialized corpus, whereas the native term rastlinstvo 'vegetation' has 2.509 occurrences in Gigafida and 0 occurrences in the specialized corpus. The native term rastlinski 'vegetative' has 25.203 occurrences in Gigafida and 3 occurrences in the specialized corpus, whereas the borrowed term vegetativni 'vegetative' has 1.307 occurrences in Gigafida and 1 occurrence in the specialized corpus.

The terminological pairs vegetacija / vegetacijski 'vegetation / vegetative' and rastlinstvo / rastlinski 'vegetation / vegetative' are used quite interchangeably in Slovene green energy terminology, even though there are some contextual differences in uses of each of the pairs in Slovene. The term vegetacija 'vegetation' refers to the 'growth and development of plants', whereas the term rastlinstvo 'vegetation' encompasses 'plants as a whole'8 . The adjective vegetacijski 'vegetative' 'refers to vegetation', whereas the adjective rastlinski 'vegetative' 'relates to plants'.

In English, the term vegetation stands for 'plant life or total plant cover (as of an area) ${ }^{10}$, whereas the term vegetative can relate to 'growing or having the power of grow-

\footnotetext{
8 The Slovene definition is taken from Slovar slovenskega knjižnega jezika (Dictionary of Standard Slovenian). Translation into English: Laura Mrhar.

9 The Slovene definition is taken from Slovar slovenskega knjižnega jezika (Dictionary of Standard Slovenian). Translation into English: Laura Mrhar.

10 "Vegetation." Merriam-Webster.com.

Accessed September 5, 2016. http://www.merriam-webster.com/dictionary/vegetation.
} 
ing', 'promoting plant growth', or 'vegetation' in general ${ }^{11}$. GREET therefore presents both terminological pairs individually, i.e., shows both rastlinstvo / rastlinski 'vegetation / vegetative' and vegetacija / vegetacijski 'vegetation / vegetative' as headwords and disregards the frequency of use as shown in the table, according to which only the terms vegetacija 'vegetation' and rastlinski 'vegetative' should be presented as headwords.

The analysis has also shown that doublets are problematic in the case of English terms which have two or more concurrently used native Slovene equivalents, e.g., onesnaževanje / onesnaženje 'pollution'. Similarly, doublets are problematic in the case of English terms which have two or more borrowed translation equivalents in Slovene, e.g., biotska raznovrstnost / biološka raznovrstnost / biotska pestrost / biodiverziteta 'biodiversity'. In some cases, the use of the native and borrowed expressions that form a terminological pair can vary. In relatively numerous terminological pairs, the borrowed term is used in specialized language and the native term in general language (7), e.g., albedo in specialized language and odbojnost in general language, whereas there are fewer instances of terminological pairs in which the native term is used in specialized language more often than the borrowed term (8), e.g., ozračje not atmosfera. Sometimes, the borrowed expression is established instead of a native expression simply because of its shorter and, therefore, more convenient form, e.g., habitat 'habitat' vs. the descriptive native equivalent naravno okolje živali 'habitat'.

(7)

- albedo / odbojnost 'albedo'

- incineracija / sežiganje 'incineration'

- meteorologija / vremenoslovje 'meteorology'

(8)

- ozračje / atmosfera 'atmosphere'

- oglenitev / karbonizacija 'carbonization'

- pomorski / maritimni 'maritime'

The variety of vocabulary used in the field can also be seen through the use of one or more synonyms for a single concept in a single Slovene article included in the corpus. One of the authors, for example, uses the term podnebna sprememba 'climate change' 26 times and its synonym klimatska sprememba 'climate change' 6 times. Another author uses the term emisija 'emission' 14 times and its unborrowed equivalent izpust 'emission' 6 times. In a different article, the expression biotska raznovrstnost 'biodiversity' occurs 15 times, whereas its synonym biotska pestrost 'biodiversity' occurs twice. One of the most interesting examples is the use of the term onesnaževalo 'pollutant' vs. polutant 'pollutant'. In one of the articles in the corpus, the authors make use of the unborrowed term onesnaževalo as many as 59 times, and only use the borrowed term polutant twice.

\footnotetext{
11 "Vegetative." Merriam-Webster.com.

Accessed September 5, 2016. http://www.merriam-webster.com/dictionary/vegetative.
} 
In the case of some terminological pairs, the borrowed term is more often used in general language than in specialized language. The borrowing klima 'climate', for example, prevails in general language and has merely 3 concordances in the specialized corpus, whereas the unborrowed term podnebje 'climate' remains preferential in specialized language, with as many as 10 concordances in the corpus. In general, however, borrowings still prove superior in specialized language, as is the case with terms like toksicni 'toxic' (not strupeni), transport 'transport' (not prevoz) and urbani 'urban' (not mestni). Many a times, the same terms from the field of green energy are used both in general in specialized language, e.g., podnebna sprememba 'climate change' (not klimatska sprememba), emisija 'emission' (not izpust), odlagališce 'landfill' (not deponija), etc.

It is the liberal, non-uniform use of borrowed expressions on the one hand and native expressions on the other that is the most problematic and, points out, at a very basic level, that Slovene green energy terminology has not been unified. It would be too presumptuous to say that Slovene green energy should be standardized, as this field is so interdisciplinary, and therefore cannot be compared to narrower fields, whose terminology is more organized - even more rigid - but green energy terminology should to some extent be regulated. The most burning issues should be addressed, especially in the case of terminological pairs. Specialized dictionaries should clearly present the preference for specific terms in cases of several terms to one concept, supported by empirical (quantitative) data obtained from corpus analyses showing a large number of instances of a given term as well as typical uses in various semantic environments, in this case related to green energy and other similar fields.

\section{Conclusions}

The analysis of borrowing from English into Slovene in the field of green energy has revealed the richness and complexity of this process and has furthermore shown the integration and co-existence of loanwords with Slovene equivalents. Even though the vast influx of new expressions along with a large amount of loanwords add semantic value to Slovene, the need for linguistic economy is stressed, especially in the case of newer fields such as that of green energy, in which the use of terminology is not as regulated or as unified as it should be. In such interdisciplinary fields, characterized by both terminologization and determinologization, which encourage broader terminological use, constant and rapid changes will continue to happen, and it will become more and more important to monitor these changes in specialized bilingual dictionaries and keep up with them, in order to keep the specialized language alive and fully functional. 


\section{References}

Crystal, David. 2011. “The consequences of global English.” In Word for Word: The Social, Economic and Political Impact of Spanish and English, edited by Philip Powell-Davies and Jaime Otero, 67-72. Madrid: Instituto Cervantes and the British Council.

Drosdowski, Günther et al., eds. 1994. Duden: Das Das Große Fremdwörterbuch. Herkunft und Bedeutung der Fremdwörter. Mannheim: Dudenverlag.

Erjavec, Tomaž. 2010. Slovenska terminologija in svetovni splet. In Nacionalni jeziki v visokem šlstuu. Zbornik prispevkov z mednarodne konference Jezikovna različnost in nacionalni jeziki $v$ visokem šolstvu / Collected Papers from the International Conference Language Diversity and National Languages in Higher Education, edited by Marjeta Humar and Mojca Žagar Karer, 109-112. Ljubljana: Založba ZRC, ZRC SAZU.

Greavu, Arina. 2014. "A Classification of Borrowings: Observations from Romanian / English Contact." Diversité et Identité Culturelle En Europe 10 (2): 95-104.

Haspelmath, Martin, and Uri Tadmor. 2009. Loanwords in the World's Languages. Berlin: Walter de Gruyter.

Haugen, Einar. 1950. "The analysis of linguistic borrowing.” Language 26 (2): 210-232.

Haugen, Einar. 1956. Bilingualism in Americas: A Bibliography and Research Guide. Alabama: University of Alabama Press.

Kranjc, Simona, and Andreja Žele. 2014. Borrowed Lexicon and Neologisms in Standard Language and Sociolects (the Case of Slovenian). In: Linguistica Copernicana (11): 113-129.

Mrhar, Laura. 2015. Bilingual Specialized Dictionary Compilation from a Translational Point of View. Unpublished doctoral thesis. Ljubljana: Filozofska fakulteta.

Onysko, Alexander. 2007. Anglicisms in German: Borrowing, Lexical Productivity, and Written Codeswitching. Berlin, New York: Walter de Gruyter.

Seidlhofer, Barbara. 2011. Understanding English as a Lingua Franca. Oxford: OUP.

Slovar slovenskega knjižnega jezika / Dictionary of standard Slovenian (Ljubljana: Slovenska akademija znanosti in umetnosti, Znanstvenoraziskovalni center znanosti in umetnosti, Inštitut za slovenski jezik Frana Ramovša ZRC SAZU, 2000), accessed September 2, 2016. http://bos.zrcsazu.si/sskj.html.

Šabec, Nada. 2009. Recent English Loanwords in Slovene. ELOPE 6 (1-2): 19-27.

Tavzes, Miloš, ed. 2002. Veliki slovar tujk. Ljubljana: Cankarjeva založba.

Vidovič Muha, Ada. 2004. Vprašanje globalizmov ali meje naših svetov. In Aktualizacija jezikovnozvrstne teorije na Slovenskem, edited by Erika Kržišnik, 73-82. Ljubljana: Filozofska fakulteta.

Vidovič Muha, Ada. 2011. Slovensko skladenjsko besedotvorje. Ljubljana: Znanstvenoraziskovalni inštitut Filozofske fakultete.

Zenner, Eline, and Gitte Kristiansen, eds. 2014. New Perspectives on Lexical Borrowing. Boston, Berlin: Walter de Gruyter.

Žele, Andreja. 2009. Enojezični slovarji - sledenje pomenskosti besed oz. kaj in kako pravi raba. In Obdobja 28: Infrastruktura slovenšcine in slovenistike, edited by Marko Stabej, 457-461. Ljubljana: Univerza v Ljubljani, Filozofska fakulteta, Oddelek za slovenistiko, Center za slovenščino kot drugi/tuji jezik. 